\title{
SLOPE STABILITY STUDIES OF WABANE CALDERA, WESTERN CAMEROON: IMPACT OF HYDROLOGY, HYDROGEOLOGY AND HUMAN FACTORS ON LANDSLIDE INITIATION
}

\author{
E. B. NTASIN, S. N. AYONGHE AND C. E. SUH \\ (Received 12, October 2007; Revision Accepted 15, September 2008)
}

\begin{abstract}
Slope analysis within the Wabane caldera was carried out to establish their stability after the $20^{\text {th }}$ July 2003 landslides. A site with semi-circular fractures was selected for the installation of a vibrating wire displacement meter and a vibrating piezometer. Displacement, rainfall and pore water fluctuation were recorded from May to December 2005 in an attempt to assess the behavior of these slopes with varying rainfall intensities throughout the period. The results indicated an increase in displacement with rainfall and pore pressure from May to September and a subsequent decrease from October to December. This demonstrates the interdependence between rainfall, pore pressure and displacement. The mean monthly rate of displacement recorded was $132.3 \mathrm{~mm} / \mathrm{month}$. The highest rate of displacement from regressive plots was approximately $0.01 \mathrm{~mm} / \mathrm{min}$ for the months of August/September. These are low threshold values, and one can therefore infer that they represent the beginning of a possibly new cycle to landslides projected to occur again in the future. Prolonged rainfall and increased pore water pressure had been determined as the immediate factors responsible for the initiation of the 2003 landslides.
\end{abstract}

KEYWORDS: Caldera, Stability, Landslide, Rainfall, Pore-water pressure, Displacement.

\section{INTRODUCTION}

In Cameroon the most frequent natural hazard is mass wasting; often resulting from heavy rainfall or associated with earth tremors. Usually the movements that occur may extend from small and slow displacements associated with creep, to rapid and larger displacements of catastrophic slides. Landslides are particularly common especially along the topographic highs that dominate the western half of the country, known as the Cameroon Volcanic Line (CVL).

The July $20^{\text {th }} 2003$ event was a spontaneous swarm of more than 120 landslides that occurred within the Wabane Caldera. It killed 23 people, displaced more than 1000 people and resulted in the loss of more than 385 livestock. The event swept away culverts and bridges thereby rendering the region inaccessible. The main activity of this region which is farming was completely obstructed due to the destruction of farms as well as locally designed irrigation schemes. Slide movements ranged from creep, slips, debris flows, to rock falls, all of which are forms of slope failure.

\begin{abstract}
Previous Work
The Wabane Caldera of Western Cameroon is widely characterized by outcropping of pyroclastic materials derived from historic volcanic activities along the Cameroon Volcanic Line (CVL) Fig 1. The thickness of these mantle deposits range from a few centimeters to tens of meters, and their morphology has been shaped by tectonics and meteorological processes. The loose pyroclastics overlie gibbsitic bands that are produced from the process of intensive weathering. Due to heavy rainfall, poor consolidation of the pyroclastics, high slope angles, high permeability contrast between the surficial pyroclastics and underlying gibbsitic bands, as well as lateral differences in permeability within the pyroclastics cover; the risk posed by these surficial deposits and the mobilization of the material as very rapid debris flow is very high.
\end{abstract}

E. B. Ntasin, Department of Geology and Environmental Science, Faculty of Science, University of Buea, P. O. Box 63, Buea, Cameroon.

S. N. Ayonghe, Department of Geology and Environmental Science, Faculty of Science, University of Buea, P. O. Box 63, Buea, Cameroon.

C. E. Suh, Department of Geology and Environmental Science, Faculty of Science, University of Buea, P. O. Box 63, Buea, Cameroon. 


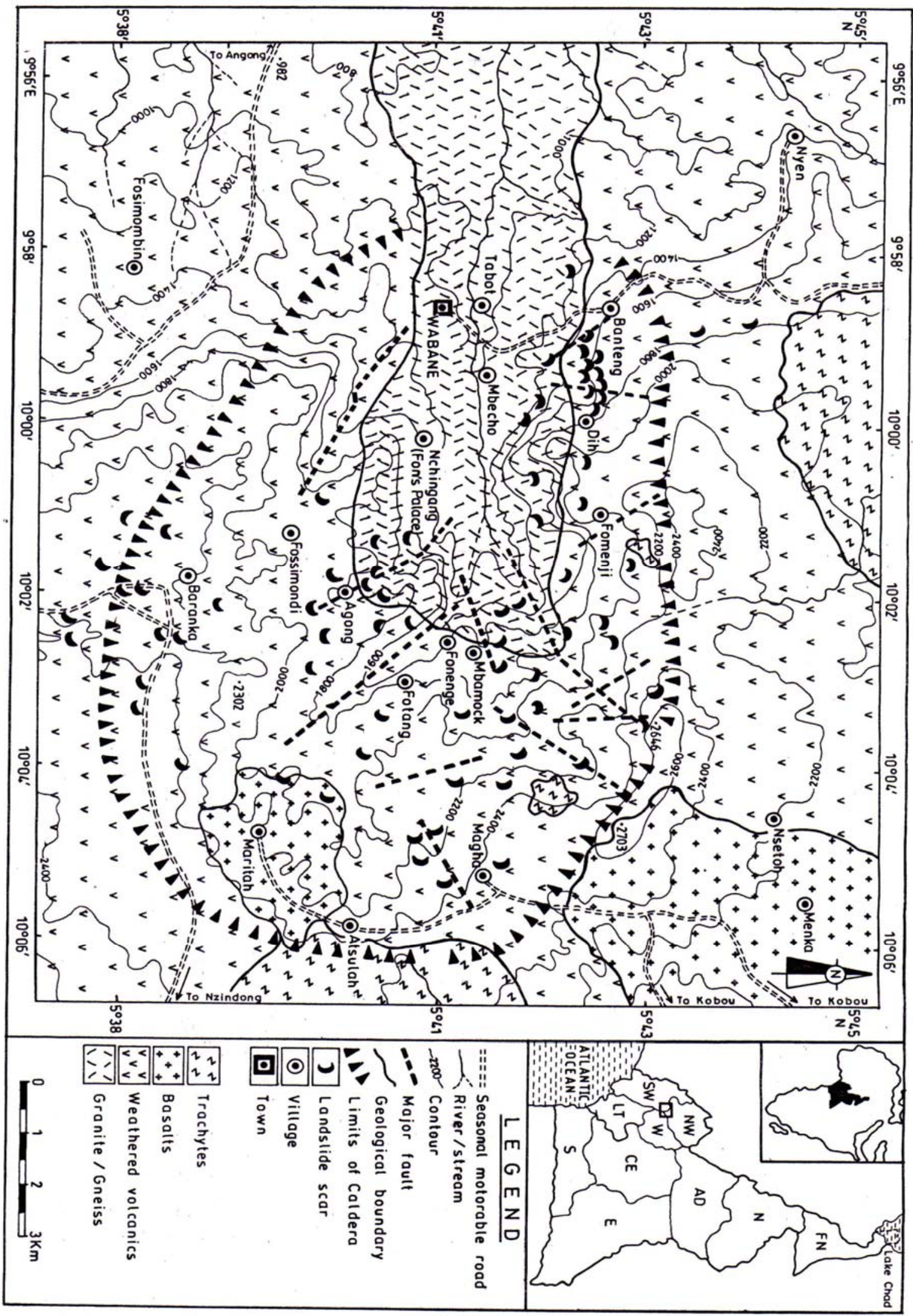

Fig 1: Geology and the distribution of landslide scars within the study area.

Instrumentation for continuous monitoring in landslide studies is becoming increasingly important because real time information as well as long term data can be obtained and utilized to avoid potential risk to the environment. The ability to assess the susceptibility of a slope to landslide and to quantify rates and mechanism of movement is important where negative economic or safety impact may result. Slow soil displacement may have a significant effect on structures, communication routes and services. Similar studies have been carried out by Angeli et al (1988) and Angeli and Casparetto (2000) who used open stand pipe piezometers in an analytical approach to obtain actual groundwater response in North Italy. Barton et al (2000) also used inclinometer and tiltmeter to monitor the high chalk cliff at Afton Down, Isle of Wight to provide traffic signals 
across a threatened road section, while Davies et al (2000) used thermisters, pore water pressure transducer and Linear Variable Differential Transducers (LVDTs) displacement equipments for field monitoring of groundwater response to winter rainfall on the west side of the Cascade Mountain in the United States of America (USA).

\section{Objectives}

The present work was aimed at evaluating the continuous impact of rainfall and pore pressure on displacement from the month of May to December, using an inclinometer and a piezometer with the view of ascertaining the stability state of the slopes after the July $20^{\text {th }} 2003$ landslide event. It was also intended to establish the displacement pattern from the early part of the wet season (May) to the latter part (December).

\section{GEOLOGY OF THE STUDY AREA.}

The Wabane Caldera constitutes part of the Bambouto highlands which, regionally, forms part of the Cameroon Volcanic Line (CVL) that stretches from the Atlantic Island of Pagalu to the Bambouto and Oku mountains in Cameroon (Dunlop and Fitton, 1979). It is located between longitudes $9^{\circ} 56 \mathrm{E}$ and $10^{\circ} 06 \mathrm{E}$ and latitudes $5^{\circ} 38^{\prime} \mathrm{N}$ and $5^{\circ} 45^{\prime} \mathrm{N}$. The Tertiary to Recent volcanics which constitute this structure are made up of a series of flows and falls that range in composition from basanites to rhyolites, trachytes, phonolites and various rhyolitic tufaceous phases (Fig 1). These rocks rest unconformably on the Pan-African syenite plutonic complex (Ayonghe and Ntasin, 2008). Isotope geochemistry dating of these volcanics gave an age of 22.7 Ma for the oldest volcanic series and 4.52 Ma for the youngest (Tchoua, 1974; Marzoli et al., 2000). These rocks have been affected by intensive weathering, producing bands of clays especially along fractured zones.

Tectonically the region was affected by the processes that produced the CVL and those responsible for the collapse that produced the caldera. Field evidence of deformation of the various rocks is discernible on a macroscopic scale from the complicated nature of fractures on both the plutonic and the volcanic complexes. Analysis of these fractures produced a trend of N20E-N40E for the plutonic complex with variable dips from $25^{\circ}-85^{\circ} \mathrm{SE}$ or NW and a dominant trend of N30E-N40E for the volcanics with dips between $35^{\circ}$ and $65^{\circ} \mathrm{SE}$ or NW (Ntasin et al., 2007). The trend for the plutonic complex closely fits with that of the normal faults of the southern part of the CVL of N20E-N30E
(Moreau et al., 1987). Relief joints with surfaces parallel to the topography are closely associated with landslide scars.

\section{MATERIALS AND METHODS}

The collection of data was guided by the fact that most of the areas that recorded landslides had earlier shown evidence of fractures at the crown regions. Therefore, the region selected for the installation of the equipment showed a series of semi-circular tension fractures. Since the occurrence of landslides is guided by seasonal changes and also based on historic records from the region the monitoring period considered was from May to December 2005.

\section{Vibrating Wire Displacement Meter (VWDM)}

The vibrating wire displacement meter (VWDM) model 4427 also known as the long range displacement meter (LRDM) (Fig 2) was installed to measure the displacement across tension fractures within a carefully chosen site. The equipment was attached to a firmly anchored post. The post was maintained with a flat surface to which the heavy base plate was attached. The mounting surface was then oriented to point in the direction of a second measuring post. The second post consisting of a heavier mount was grouted into the ground at a distance of $120 \mathrm{~m}$. A specifically designed extension cable was used to cover the distance between the two posts. The weak link was threaded onto the end of the aircraft cable and secured by cable clamps. The extension cable was looped through an eyebolt on the second measuring post and was tensioned so that there was a slight initial movement of the vibrating wire transducer inside the 4427 model enclosure.

The 4427 model equipment was then connected to a readout box; model GK - 404 vibrating wire readout (VWR) and the extension cable tightened and allowed to stabilise for sometime. After the stabilization, the initial reading (Ro) was taken on channel $B$ of the vibrating wire readout. Then subsequent readings were taken twice a day during the early hours of the morning and in the evening, and daily magnitude of any movement calculated from the formula:

$$
D=G(R t-R o)
$$

$$
\begin{aligned}
& \text { Where } \\
& D=\text { Displacement } \\
& G=\text { Calibration factor in } \mathrm{mm}(0.2476 \mathrm{~mm} / \text { digit }) \\
& \text { Ro = Initial reading } \\
& \mathrm{Rt}=\text { Subsequent reading }
\end{aligned}
$$




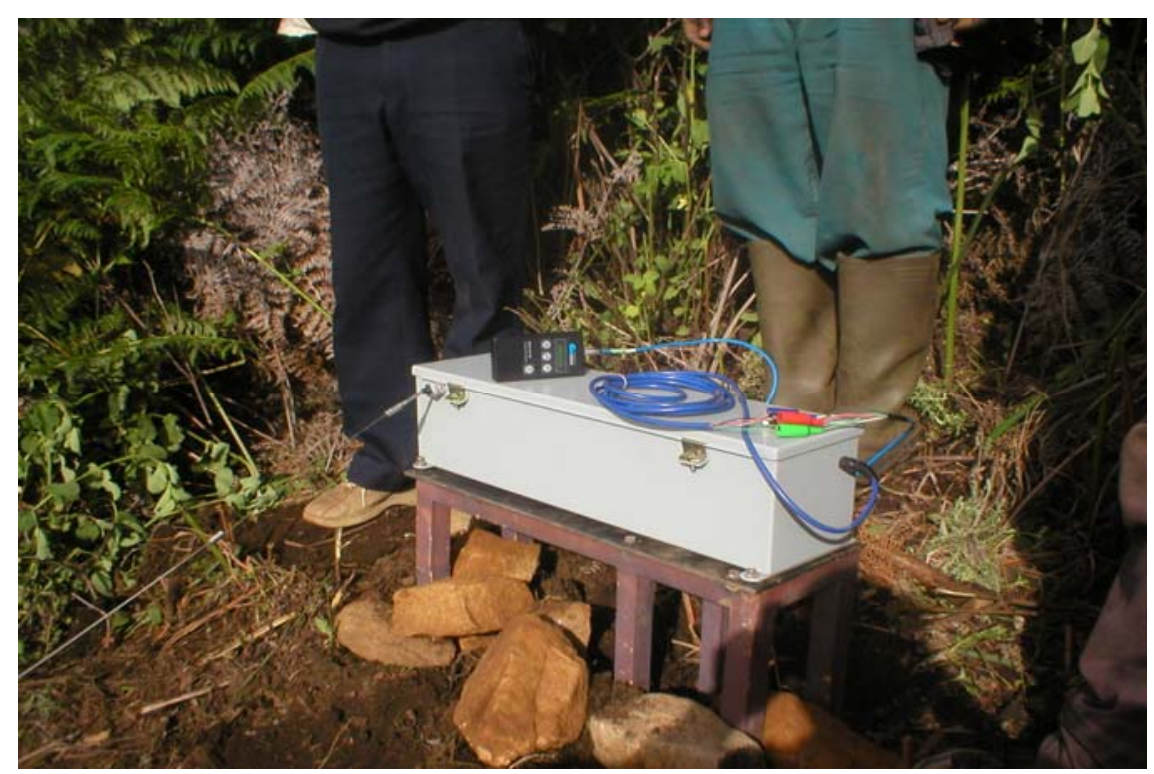

Fig 2: The Long Range Displacement Meter, LRDM (white box) and the Read-Out Meter (black case), installed at Magha.

\section{Vibrating Wire Piezometer}

The second equipment installed was a "Geokon Model 4500s vibrating wire piezometer' used to obtain the pore water pressure (Fig 3). The initial step was to ensure that the filter had complete saturation. After de-airing, the transducer was immediately embedded into the soft overburden within the pit to avoid air entering the filter. When installed, an accurate initial zero pressure reading was obtained by allowing it to thermally stabilize in a constant temperature environment. Subsequent readings were also recorded twice a day on channel $B$ of the vibrating wire read out (GK-404 model) for the determination of daily and monthly pressure changes using the formula:

$$
\begin{aligned}
& P=\left(R o-R_{1}\right) G \\
& \text { Where } \\
& \qquad \begin{array}{l}
P=\text { Pressure } \\
\text { Ro }=\text { initial Reading } \\
\mathrm{R}_{1}=\text { current reading } \\
\mathrm{G}=\text { calibrated factor }(0.1246 \mathrm{kPa} / \text { digit })
\end{array}
\end{aligned}
$$

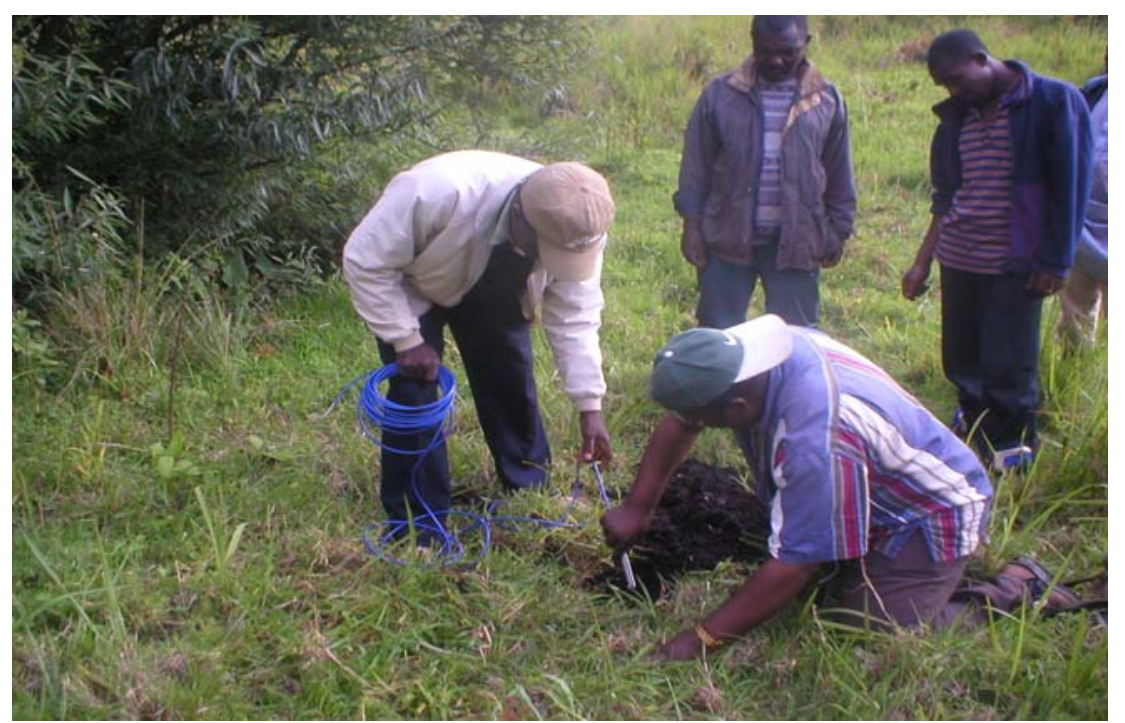

Fig 3: Installing the 4500 S Vibrating Wire Peizometer at Magha. (Author holding the Peizometer to be installed).

\section{Rainfall Data}

Based on local realities and a community-based approach on providing risk indicators, a semi quantitative method was used in recording rainfall. This was based on rainfall duration, not the amount of rainfall. Records were obtained at 12 hours interval and rainfall incidences were noted twice a day (morning and evening). Rainfall event was indicated by the letter $\mathrm{Y}$, and no rainfall was indicated by $\mathrm{N}$. Although a semiquantitative method, it provided some idea on a duration-quantity threshold responsible for triggering the landslides. Each day had two indications and the values " $1,2,4,5,6,7,8,9,10$ " assigned to the day depending on the record of the previous day, except for grade $E$ and $F$ where two days were considered by taking the second halve of the first day. 


$\begin{array}{ccccccccccc}\text { A } & \text { B+ } & \text { B } & \text { C+ } & \text { C } & \text { D+ } & \text { D } & \text { E } & \text { F } & \text { A } & 10 \\ \text { Y } & \text { N } & \text { Y } & \text { N } & \text { Y } & \text { Y } & \text { Y } & \text { Y } & \text { N } & \text { B+ } & 9 \\ \text { Y } & \text { Y } & \text { N } & \text { Y } & \text { N } & \text { N } & \text { N } & \text { N } & \text { N } & \text { B } & 8 \\ \text { Y } & \mathrm{Y} & \mathrm{Y} & \mathrm{Y} & \mathrm{Y} & \mathrm{N} & \mathrm{N} & \mathrm{N} & \mathrm{N} & \mathbf{C +} & 7 \\ \mathrm{Y} & \mathrm{Y} & \mathrm{Y} & \mathrm{N} & \mathrm{N} & \mathrm{Y} & \mathrm{N} & \mathrm{N} & \mathrm{N} & \text { C } & 6 \\ & & & & & & & \mathrm{~N} & \mathrm{~N} & \mathbf{D +} & 5 \\ & & & & & & & & & \text { D } & 4 \\ & & & & & & & & & \text { E } & 2 \\ & & & & & & & & & \text { F } & 1\end{array}$

These values were also given the grades of " $F, E, D$, $\mathrm{D}+, \mathrm{C}, \mathrm{C}+, \mathrm{B}, \mathrm{B}+$, and $\mathrm{A}$ " respectively. The assignment of values was based on the regrouped patterns indicated above.

\section{RESULTS AND DISCUSSION}

Mapping of the rock types in the study area indicated variations in the composition of the volcanics (basanite, trachytes and rhyolite). Stress relief joints were common in gibbsite. These gibbsitic bands acted as aquicludes, producing perched aquifers above. The implication here is that infiltration due to rainfall and hence pore-water pressures depend on the geology and the season. According to Davies et al. (2000), the presence of the impermeable gibbsite layers is important in determining the distribution of pore -water pressure within the subsurface. Yuki et al (2006) have also revealed that the hydraulic conductivity near the surface had a value in the order of $10^{-5} \mathrm{~m} / \mathrm{s}$ and the conductivity fell abruptly to $8 \times 10^{-7} \mathrm{~m} / \mathrm{s}$ at a depth of $0.7 \mathrm{~m}$, and further reduced to $5 \times 10^{-8} \mathrm{~m} / \mathrm{s}$ at depth of $0.9 \mathrm{~m}$. This confirms the results of this study that the zone below the gibbsitic band with great reduction in hydraulic conductivity experienced a high pore-water pressure especially after prolonged rainfall.

The monthly variation in displacement (Table 1) indicates an increase from May to September, followed by a drop from October to December. The analyses indicate that slow, shallow or deep landslides, especially those associated with clayey materials, are normally a consequence of moisture and pore water pressure changes within existing zones. The three curves: rainfall, pore-water pressure, and displacement (Figs 4a-g) show very close correlations indicating their interdependence. It is therefore evident that the interplay of rainfall and pore-water pressure is an important component in the initiation of landslides. Reasonable displacement can easily be linked to a preceding rise in pore water pressure. For example, the sudden rise in pressure of $4.9 \mathrm{KPa}$ on the $16^{\text {th }}$ day of June was followed by a displacement of $179.8 \mathrm{~mm}$ on the $18^{\text {th }}$ of June (Fig $4 \mathrm{~b}$ ). Recent slope stability analyses have examined such a realistic hydrological response and proved rain infiltration and subsequent redistribution of groundwater pressure as sufficient components for triggering landslides (Gasmo et al, 2000; Cho and Lee, 2001; Collins and Znidaric, 2004).

Table 1: The Displacement rates from May to December.

\begin{tabular}{|l|l|l|l|l|l|l|l|}
\hline Бy/Бx & \multicolumn{6}{l|}{ RATE OF DISPLACEMENT } \\
\hline & MAY & JUNE & JULY & AUG/SEPT & OCT & NOV & DEC \\
\hline $\mathrm{mm} / \mathrm{hrs}$ & 0.08 & 0.17 & 0.19 & 0.36 & 0.17 & $6.94 \times 10^{-4}$ & 0.003 \\
\hline $\mathrm{mm} / \mathrm{min}$ & 0.0014 & 0.0030 & 0.0031 & 0.006 & 0.003 & $1.2 \times 10^{-5}$ & $5.0 \times 10^{-5}$ \\
\hline
\end{tabular}

The general displacement pattern shows an increase in instability from May to September, representing the peak of the wet season and a decrease in displacement (increase in stability) from October to December which signifies a change from the peak of the wet season to the start of the dry season (Figs 4a-g). Therefore rainfall in May initially assists in the attainment of the saturation state of the rocks. In this case, wetting from land surface migrates into subsoil without a significant pressure head.
Subsequent rainfall with time results in the redistribution of the incoming rainwater, causing reduction in cohesive strength of the material above the impermeable gibbsitic bands. When the pressure reaches a critical point, it causes a small but significant movement on the slope. This concept of landslide initiation has been supported by a simulation of pore pressure diffusion associated water infiltration perpendicular to the surface of movement (Collins and Znidarcic 2004). 


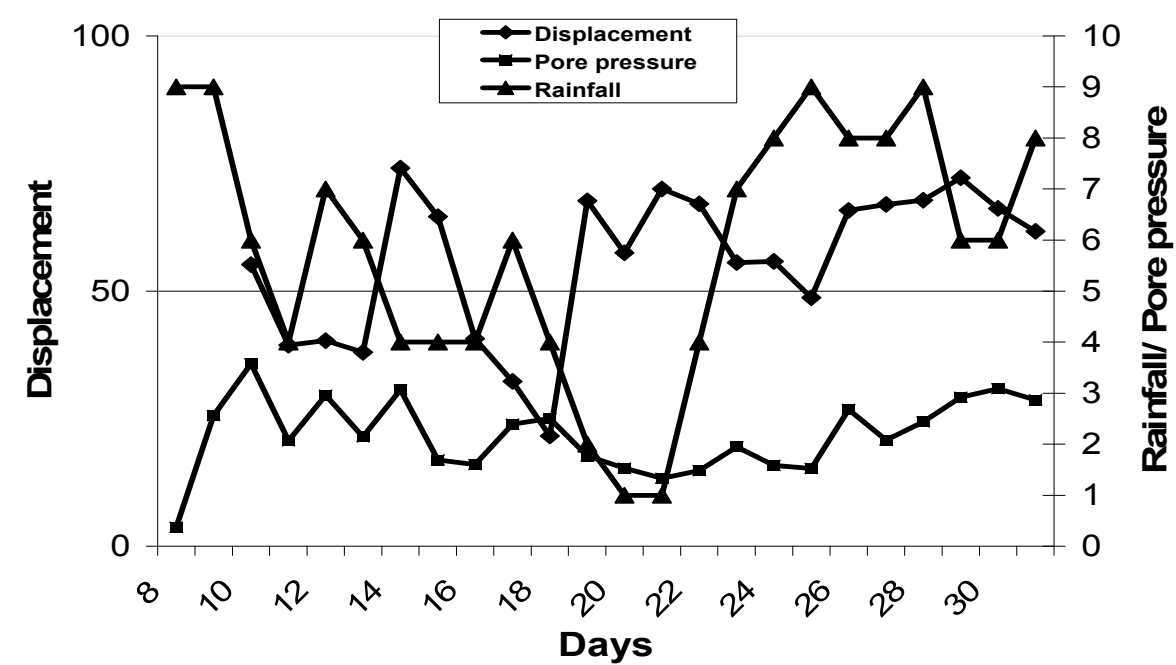

Fig 4a: Changes in rainfall, pressure, and displacement with time in May 2005.

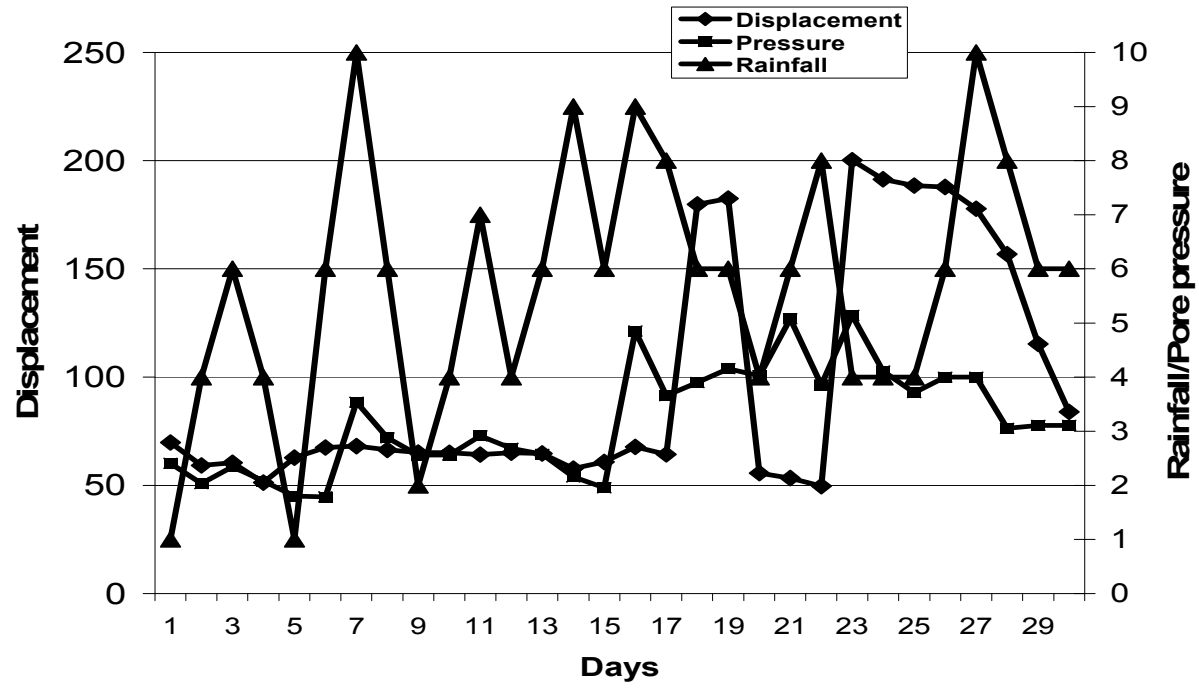

Fig 4b: Changes in rainfall, pressure, and displacement with time in June 2005.

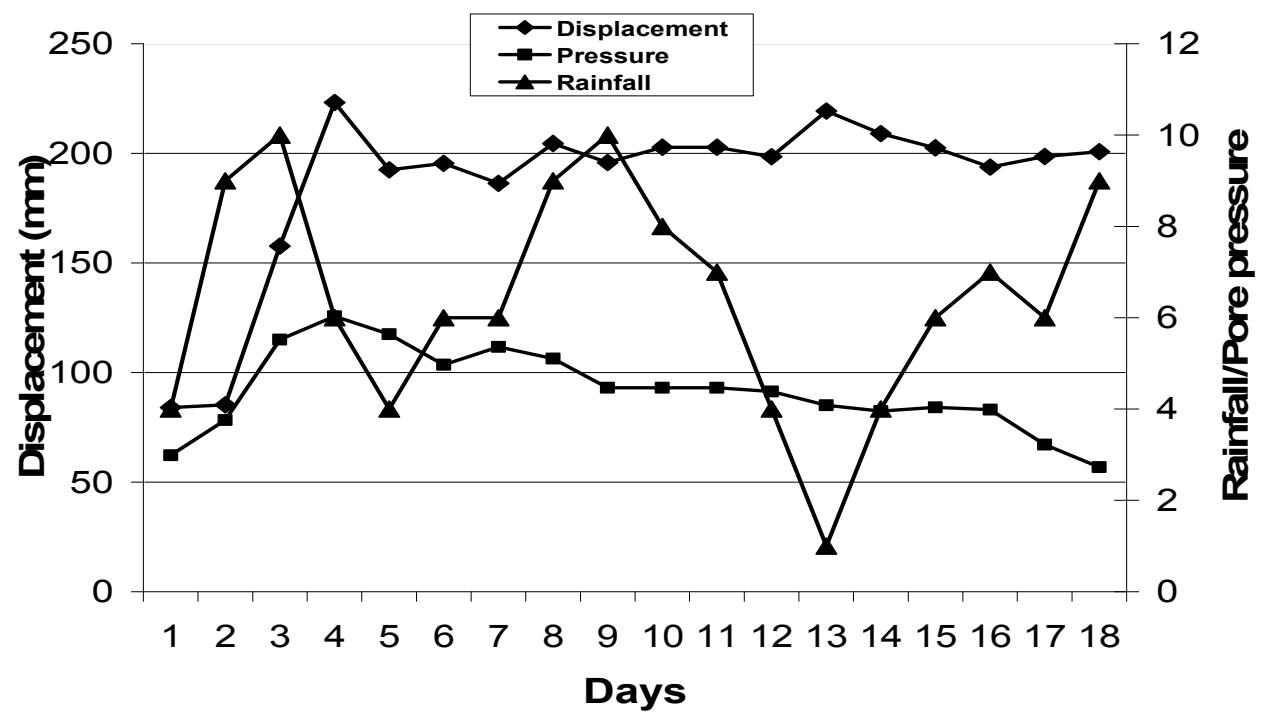

Fig 4c: Changes in rainfall, pressure, and displacement with Time in July 2005. 


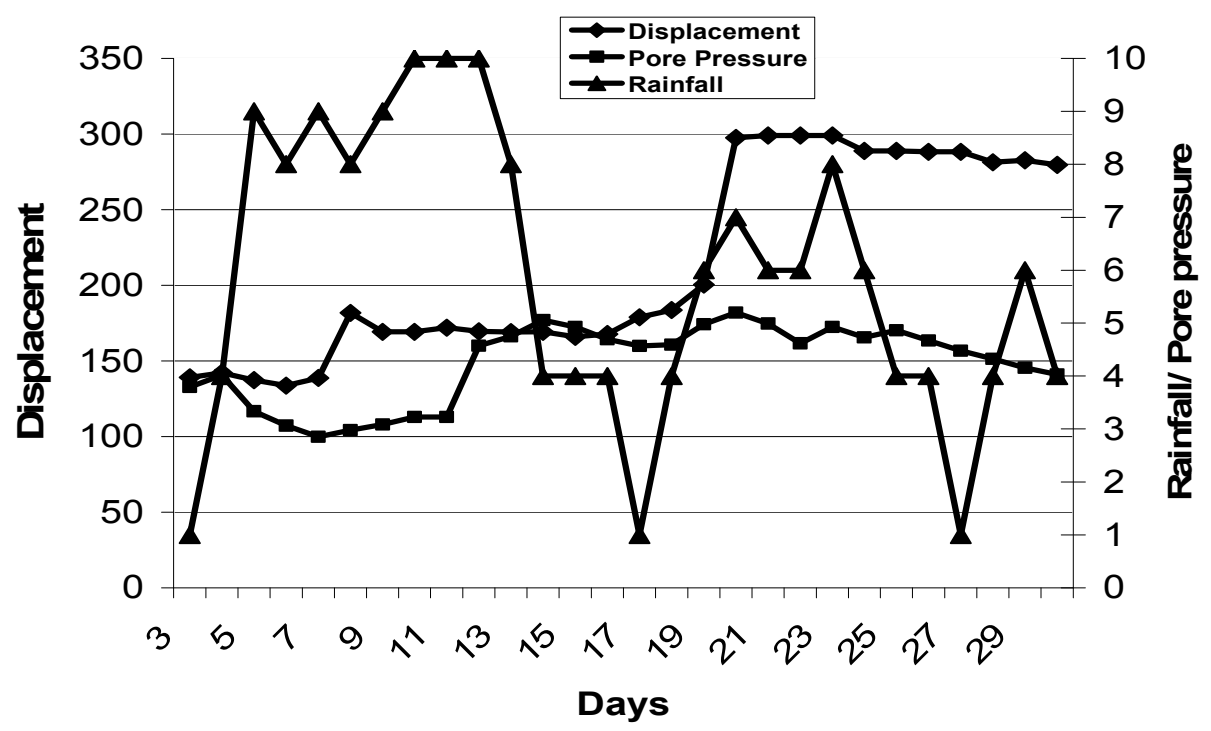

Fig 4d: August/September changes in rainfall, pressure, and displacement with time in August/September 2005.

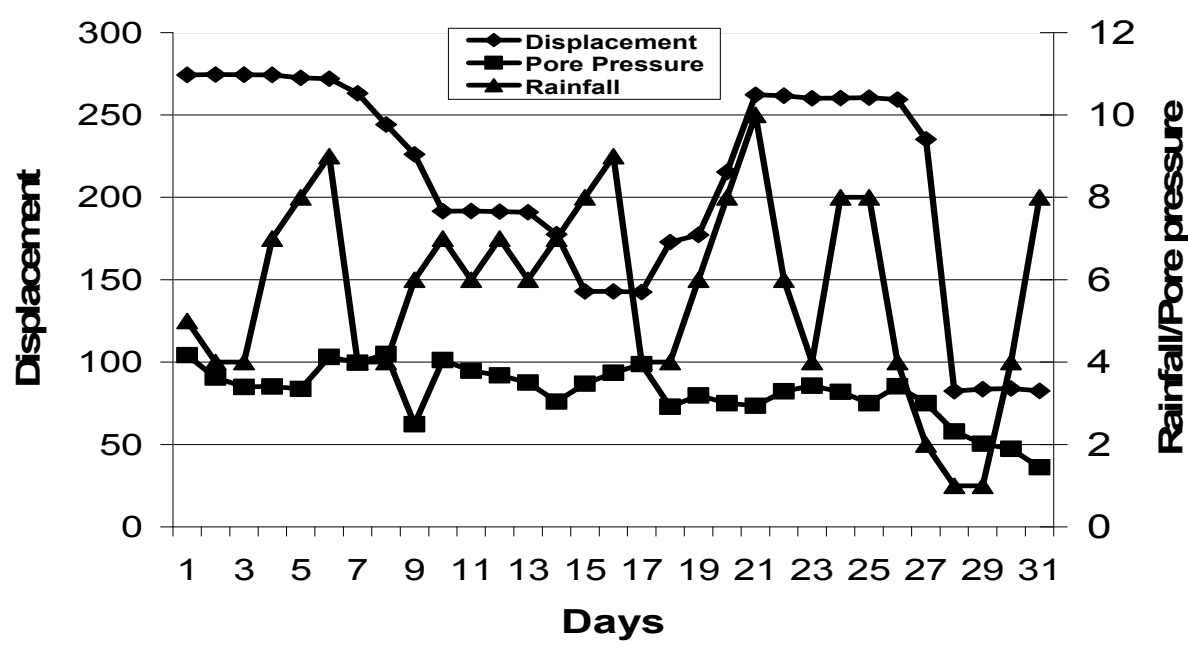

Fig 4e: Changes in rainfall, pressure, and displacement with Time in October 2005.

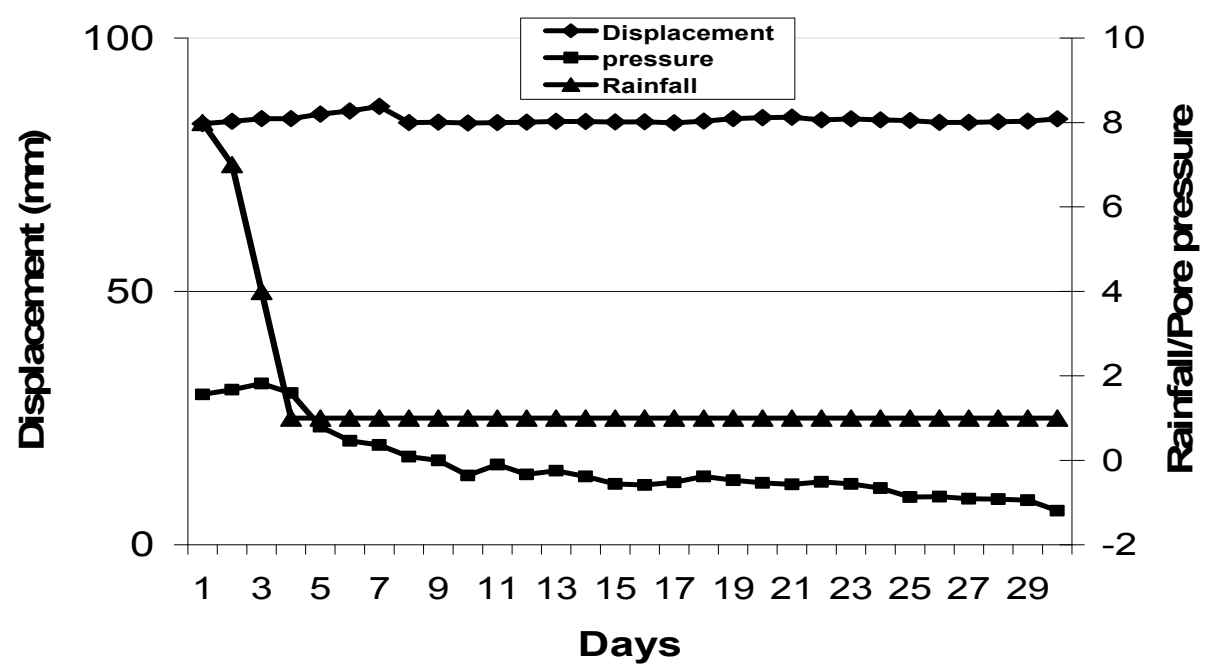

Fig 4f: Changes in rainfall, pressure, and displacement with time in November 2005. 


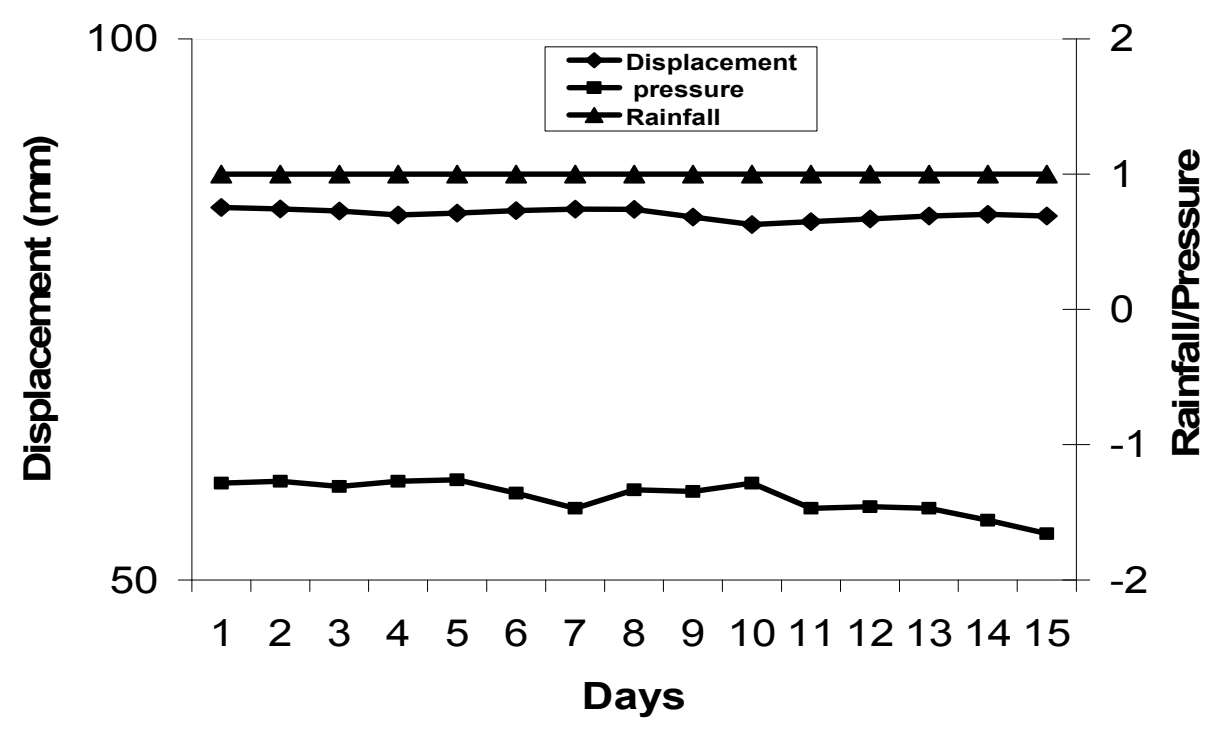

Fig 4g: Changes in rainfall, pressure, and displacement with time in December 2005

The monthly rate of movement determined from the regression plots indicate an increase from May $(0.0014 \mathrm{~mm} / \mathrm{min})$ to September $(0.006 \mathrm{~mm} / \mathrm{min})$, followed by a continuous decrease from October to December $5.0 \times 10^{-5} \mathrm{~mm} / \mathrm{min}$ (Fig 5a-g). These analyses suggest that the development and occurrences of landslide is usually a progressive and dynamic process. Despite the series of small movements recorded by the displacement meter, no landslide occurrence was recorded within the period, confirming the suggestion that any major landslide observed is the cumulative effect of many small processes of progressive deformation. Similar observations that support the progressive and dynamic process of landslides have been made in some recent works (Chem and Lee, 2003; Segalini and Giani, 2004). Babu and Murthy (2005) also supported this concept by producing a simple model to calculate the reliability for gradual failure of homogenous soil slopes.

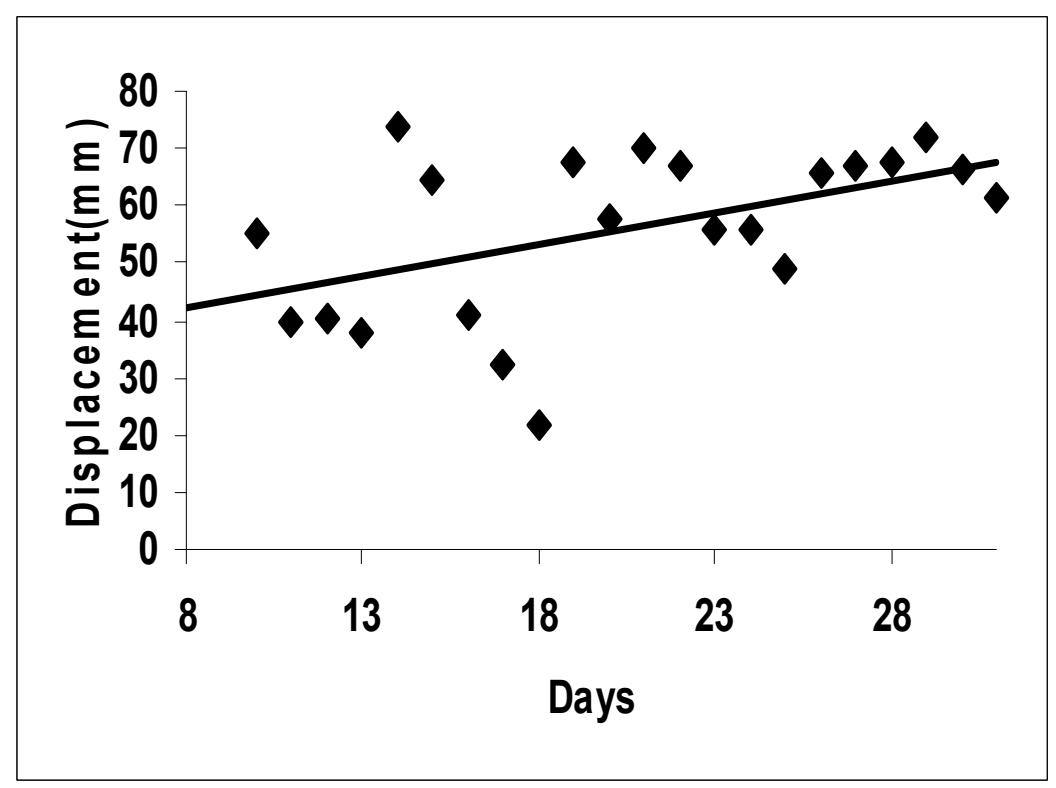

Fig 5a: Regression Plot for May 2005. 


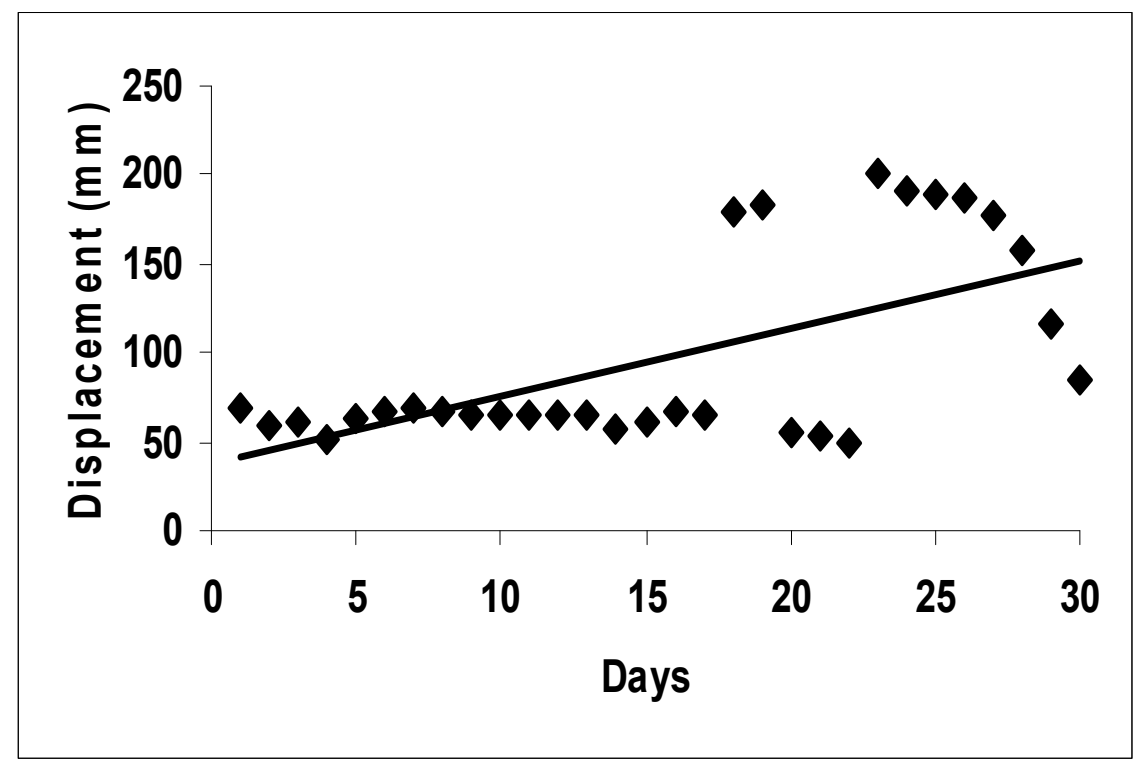

Fig 5b: Regression Plot for June 2005.

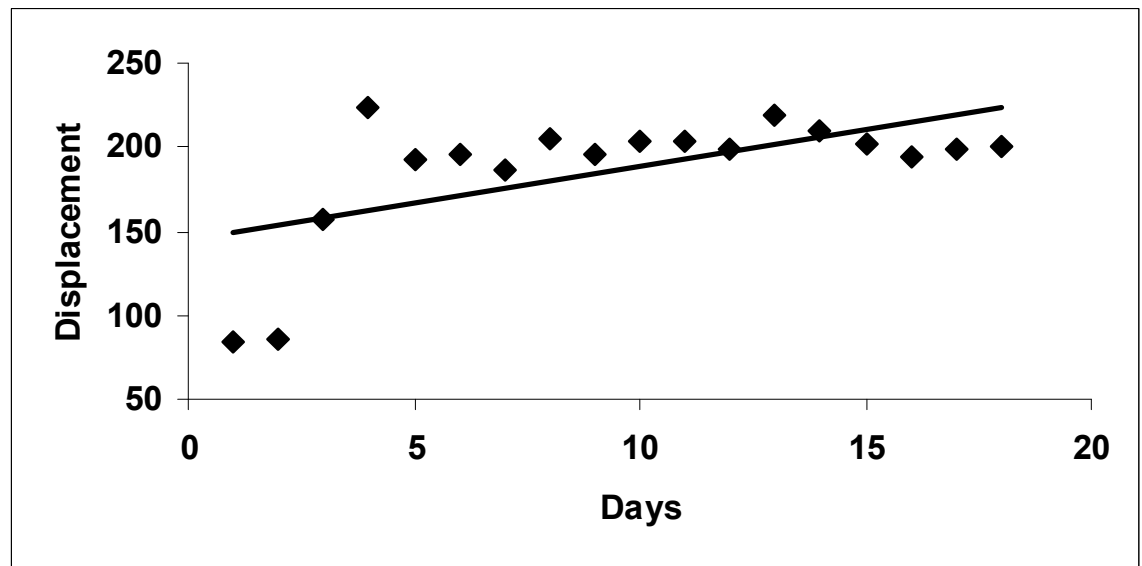

Fig 5c: Regression Plot for July 2005.

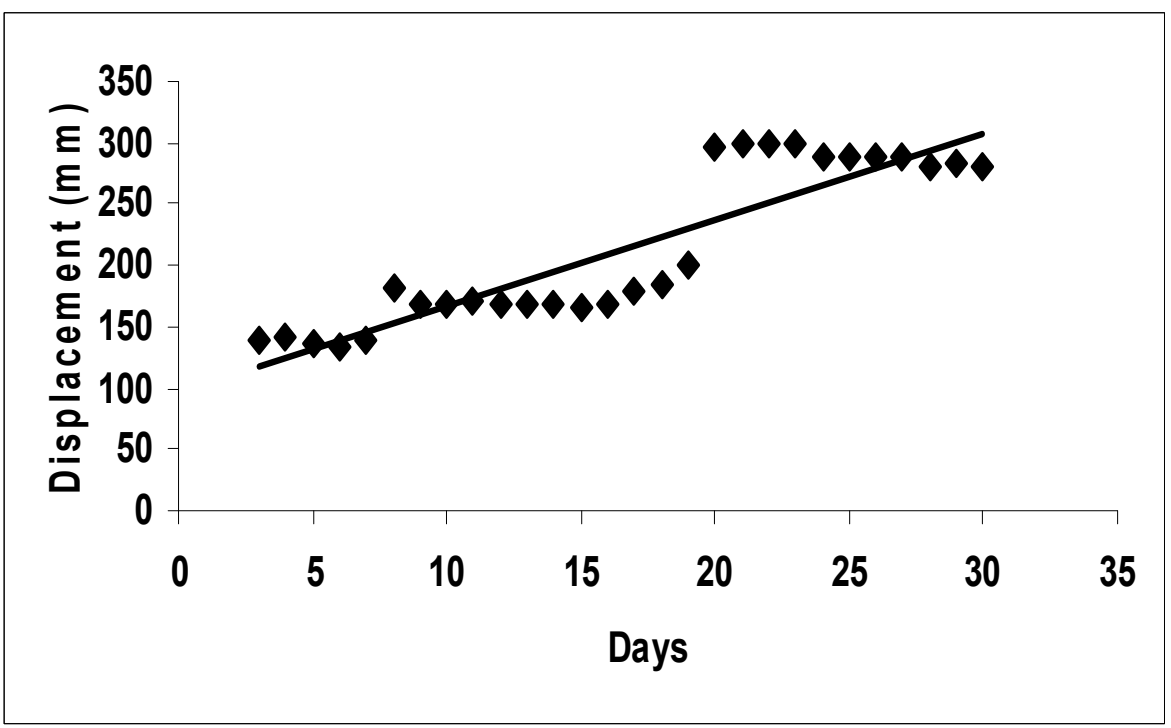

Fig 5d: Regression Plot for August/September 2005. 


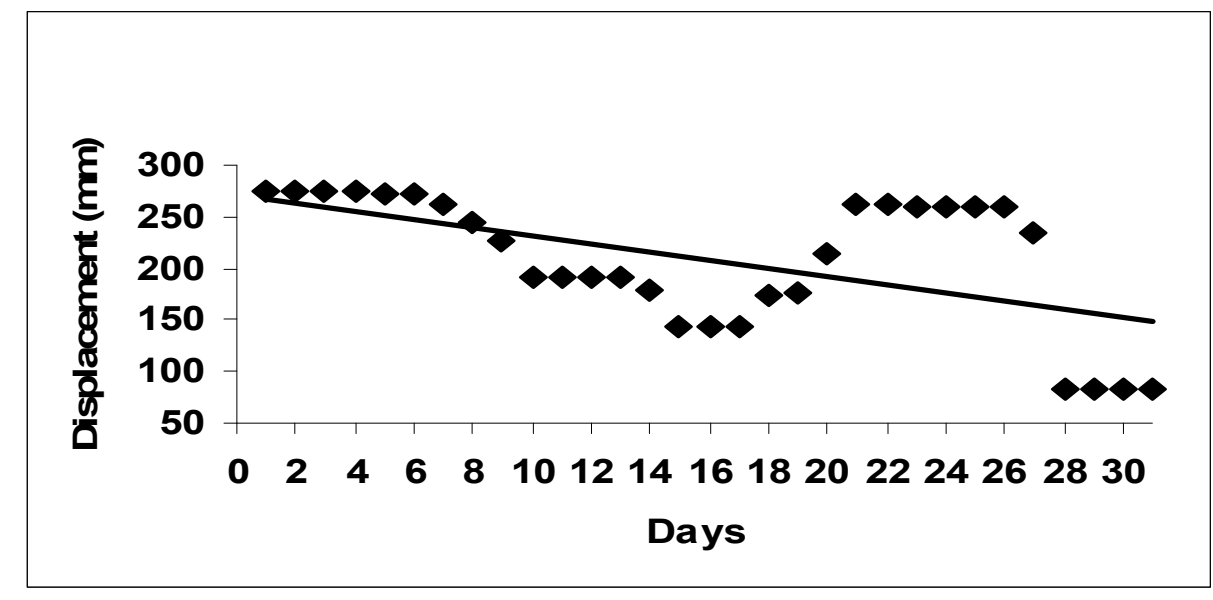

Fig 5e: Regression Plot for October 2005.

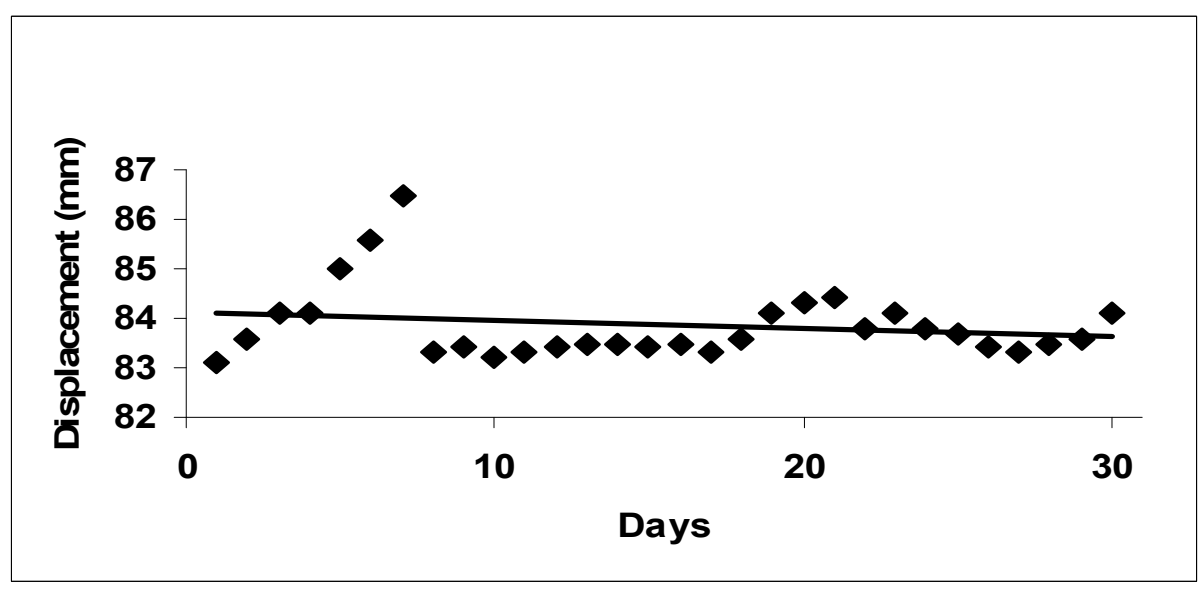

Fig 5f: Regression Plot for November 2005.

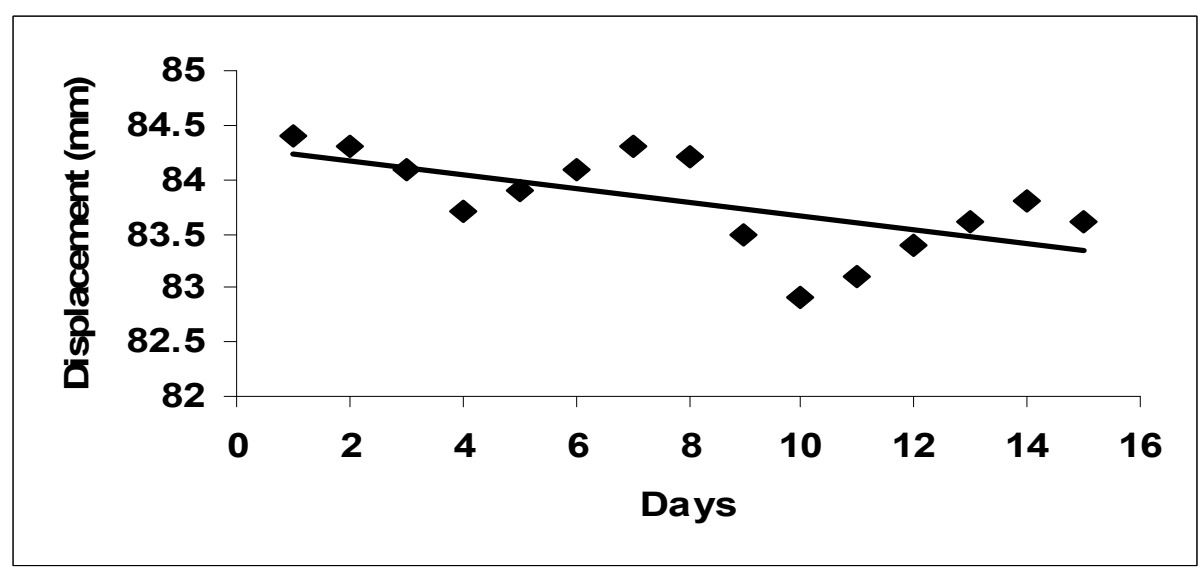

Fig 5g: Regression Plot for December 2005.

According to Zheng et al (2003) classification, the displacement recorded can be classified as large deformation. This represents the initial stage that can grade into tiny sliding and finally ending up with strong sliding. The present deformation is likely the initial stage of a new cycle, since the region prior to the installation of the displacement meter experienced on extensive landslide event and the fractures might have released the internal stresses thereby stabilizing the region.
The mean monthly rate of displacement recorded was $132.3 \mathrm{~mm} / \mathrm{month}$ while the displacement recorded before the Choja landslide (Hiura and Hiramatse, 1999) was $228.3 \mathrm{~mm} / \mathrm{month}$, which is almost twice the Webane value. Omar and Ratnasamy (2003) during the reconstruction of the Gunung Tempurung landslide in Malaysia, used instrumentation (soil strainmeter) to enable real time monitoring of ground movement and provided early warning signs to workers at a 
construction site. They established two rates of movements based on the rate of displacement (ROD). The lower threshold value had an ROD of $0.05 \mathrm{~mm} / \mathrm{min}$ and the higher value of $0.1 \mathrm{~mm} / \mathrm{min}$ which is considered higher than the Wabane case with the highest recorded value of $0.006 \mathrm{~mm} / \mathrm{min}$. Hence, this value is far below the lower threshold set by Omar and Ratnasamy (2003). This implies that at the time of this study, the potential threat posed by these slopes is very low and it goes further to support the idea that this may be the initiation of another cycle, following the $20^{\text {th }}$ July 2003 catastrophic event.

The July $20^{\text {th }} 2003$ event was a spontaneous catastrophe with more than 120 landslides occurring across the entire caldera. According to information from the local inhabitants, the reoccurrence of such major events is 10 to 12 years. Findings from this work has established that deforestation, geological setting, increased farming activities, increased population and infrastructures and consequent increased weathering, are some of the factors that have increased the risk of landslide occurrence in the region. Parblue Technologies et al. (2004) have used 1988 and 2002 satellite images to point out that deforestation and increased infrastructure are some of the major factors responsible for the occurrence of these landslides. Hiura and Hiramatsu, (1999) indicated that a critical mean monthly rate of displacement of $228.3 \mathrm{~mm} /$ month was established for the Choja landslide and Omar and Ratmasamy (2003) indicated that the record of 0.10 $\mathrm{mm} / \mathrm{min}$ was the critical value for the Gunung Tempurung landslides. It is likely that the 2003 Wabane event attained such values before the major event.

\section{CONCLUSIONS}

Based on data presented in this study, it has been concluded that the development of landslides is progressive and dynamic in the study area. It is also worth noting that external factors such as rainfall and groundwater level can fluctuate greatly with changes in season; a sudden change in these factors can thereby reverse a seemingly normal condition to highly risky within a shorter time interval. The majority of studies around the world make use of single parameters such as the displacement equipments, pore pressure changes or rainfall data to evaluate the stability of slopes. The use of these three parameters in this work has reduced to a greater extent the chance of misleading information, which can result from transient groundwater phenomena occurring in natural slopes. However, it is always possible to obtain data leading to erroneous conclusions as regards the understanding of the mechanism at work in the landslide situations. Despite the fact that the data obtained is indicating generally stable slope at the moment, the reversal in conditions within a short period can be dramatic.

\section{ACKNOWLEDGMENT}

We appreciate the support of the Faculty of Science, University of Buea, Cameroon; for the financial support towards the realization of the PhD thesis of Dr Ntasin E.B from which this article has been derived as well as the article on "The geological control and triggering mechanism of landslides of $20^{\text {th }}$ July 2003 within the Bamboutos Caldera, Cameroon" published in the Journal of the Cameroon Academy of Sciences, Vol. 7, No 3, pp137-260, May 2008. .Special thanks go to Dr Brian Dorwart of Aldrich Company USA, for his special contribution towards the field work.

\section{REFERENCES}

Angeli, M. G and Gasparetto, P. 2000. An analytical approach to obtain the actual groundwater response using open standpipe piezometer. Proceedings of the $8^{\text {th }}$ International Symposium on Landslides, Cardiff. UK, June 2000.

Angeli, M. G., Gasparetto, P., Silvano, S., 1988. An automatic recording system to detect the critical stability conditions in slopes. Proc. Int. Symposium on landslides, Lausanne, vol. 1. pp. 375- 378.

Ayonghe S.N and Ntasin E, B 2008. The geological control and triggering mechanism of landslides of $20^{\text {th }}$ July 2003 within the Bamboutos Caldera, Cameroon. Journal of the Cameroon Academy of Science. Vol 7, No 3, pp 137-260, May, 2008.

Babu, G. L. S., Murthy, D. S. N. 2005. Reliability analysis of unsaturated soil slope. Journal of Geotechnical and Geoenvironmental Engineering. ASCE 131 (11): 1423-1428.

Barton, M. E. and McCosker, A. M. 2000. Inclinometer and Tiltmeter Monitoring of a high chalk cliff. Proceedings of the $8^{\text {th }}$ International Symposium on Landslides, Cardiff. UK, June 2000.

Chem, H., Lee, C.F. 2003. A dynamic model for rainfallinduced landslides on natural slopes. Geomorphology 52: 269-288.

Cho, S. E., Lee, S. R. 2001. Instability of unsaturated soil slopes due to infiltration. Computer and Geotechnics 28: 185- 208.

Collins, B. D., Znidarcic, D. 2004. Stability analysis of rainfall induced landslides. Journal of Geotechnical and Geoenvironmental Engineering 130: 362-372.

Davies, M. C. R., Harris, C., Smith, F. W, and Berthling,

I. T. 2000. Field Monitoring of Cryogenic Mass Movement. Proceedings of the $8^{\text {th }}$ International Symposium on Landslides, Cardiff. UK, June 2000.

Dunlop, H. M and Fitton, J, G 1979. A K-Ar and Sr-isotopic study of the volcanic island of Principe, West Africa. Evidence for mantle heterogeneity beneath the Gulf of Guinea. Contrib. Mineral. Petrol. 71: 125-131. 
Gasmo, J. M., Rehardjo, H., Leong, E.C. 2000. Infiltration effects on stability of a residual soil slope. Computer and Geotechnics 26: 145-165.

Hiura, H., Hiramatsu, H. 1999. The movements and the counter-measures of the 'Choja landslide'. Landslides. Proceedings of the Ninth International Conference and Field Trip on landslides. Bristol, Uk, 5-6 Sept, 1999: 65-72.

Kim, J., Jeong, S., Park, S., Sharma, J. 2004. Influence of rainfall induced wetting on the stability of slopes in weathered soils. Engineering Geology 75: 251-262.

Marzoli, A., Piccirillo, E. M., Renne, P. R., Bellini, G., Lacumin, M., Nyobe, J. B., Tongwa, A. F. 2000. The Cameroon Volcanic Line Revisited: Petrogenesis of continental basaltic magmas from lithospheric and asthnospheric mantle sources. Journal of Petrology 41: 87-109.

Moreau, C. Regnoult, J. M. Deruelle, B; Robineau, B. 1987. A tectonic model for the Cameroon Line, Central Africa. Tectonophysics, 39: 317-334.

Ntasin, E. B., Ayonghe, S. N and Suh, C. E. 2007. The Geology and structural setting of the Bambouto caldera: Cameroon ( In Press).

Omar, $\mathrm{H}$ and Ratnasamy, M., 2003. An early warning system for active landslides. Quarternary
Journal of Engineering Geology and Hyrology, 34: 299-305

Parblue Technologies., Zogning, A., Ojuku, T. 2004. Landslide Assessment and Prevention of future risk Monts Bamboutos, Cameroon. Understanding the causes of landslides, using satellite imagery. Projection UTM WGS 1984. Landsat-4, 02 FEB 1988 and Landsat-7, 15 MAY 2002.

Segalini, A., Giani, G.P. 2004. Numerical model for the analysis of the evolution mechanism of the Grossgufer rock slide. Rock mechanics and Rock Engineering 37 (2): 151-168.

Tchoua, F. M. 1974. Contribution a l'étude géologique et pétrographique de quelques volcans de la Ligne du Cameroun. (Mount Bambouto et Manengouba). Thèse Doctorat D'Etat Universite Clermont Ferrand, France: 347.

Yuki. M; Tsuyoshi. H and Yukinori. M. 2006. Mechanism of shallow landslides on soil-mantle hillslopes with permeable and impermeable bebrocks in the Boso Peninsular, Japan. Geomorphology, Vol. $76:$ 92-108.

Zheng, Yingren, Shi, W. M., and Tang, B. M. 2003. Problems on investigation of landslides in the Three Georges reservoir Zone. Chongqing Building Magazine 1, pp 6-10. Pure and Applied Geophys, Vol. 157, No 6-8: 957-976. 